\title{
Laboratory determination of direct shear strength of granitoid rocks; examples from the host rock of the nuclear waste storage facility of Bátaapáti (Hungary)
}

\author{
Ildikó Buocz, Nikoletta Rozgonyi-Boissinot, Péter Görög, Ákos Török* \\ Department of Construction Materials and Engineering Geology \\ Budapest University of Technology and Economics, Budapest
}

\begin{abstract}
This paper provides test results and interpretation of the shear strength of granitic rocks. The samples were obtained from Bátaapáti (South Hungary), where the low and medium-activity nuclear waste storage facility of Hungary is under construction. The experiments were carried out under laboratory conditions by using direct shear strength tests of samples drilled and cut from larger granitic blocks. The friction angles of both the maximal and residual shear stress, as well as the cohesion, were detected for various joint systems and also for the cut surface of the granitic rock. The interpretation of test results includes the evaluation of normal stress versus shear strength for cut, moderately rough, rough and calcite-filled joints. The tests have demonstrated that the average internal angle of friction for granitic rocks exceeds $20^{\circ}$, with a maximum of $39^{\circ}$ for rough surfaces. Calcite-filled joints have lower friction angles, in the range of $16-23^{\circ}$. The peak shear strength of granitic test specimens was between 0.8 and $4.1 \mathrm{MPa}$, depending on the surface and joint fill.
\end{abstract}

Key words: direct shear strength, granite, radioactive waste disposal, joint, angle of friction

\section{Introduction}

Shear strength tests play an important role in assessing the behavior of rock masses. The pioneering work of Patton (1966), Ladanyi and Archambault (1970), and Barton and Choubey (1977) established the fundamentals of the theories of direct shear strength tests that are still used today. The testing methodology and various types of test apparatus have been described in detail in International Society for Rock Mechanics (ISRM 1974). The results of shear strength tests have been applied successfully in describing the behavior of slopes and rock masses

\footnotetext{
Addresses: I. Buocz, N. Rozgonyi-Boissinot, P. Görög, Á. Török: H-1111 Budapest, Sztoczek u. 2, Hungary, *Corresponding author: torokakos@mail.bme.hu

Received: March 3, 2011; accepted: May 11, 2011
} 
that were affected by landslides. Towhata et al. (2001) demonstrated that sandstone and black mudstone with very low shear strength were involved in earthquake-triggered landslides. Failure along discontinuities is strongly influenced by the joint-filling material and surface roughness. Joint Roughness Coefficient (JRC) can be used to assess shear strength, but due to the original determination of JRC the method has limitations: it only provides a twodimensional description of the surface. The sheared surface is better modeled when the surface is scanned in 3D. Grasselli (2001) used an ATR scanner to map the surface irregularities and outlined a new formula that better explains the relationship between JRC and shear strength for rocks of various lithologies. A 3D direct shear box (BCR3D) was used to test the calcite discontinuities in granodioritic rock of Central France that hosts a nuclear waste storage facility. Low shearing rate was used under constant normal force and stiffness, by using samples of $40 \times 40 \mathrm{~mm}$ in size. The plane of the joint was more or less parallel to the plane of shearing. Both intact and intentionally separated joints were tested. For open joints angles of friction $32.5^{\circ}$ and $42.1^{\circ}$, and for closed joints $42.1^{\circ}$ and $53.5^{\circ}$ were detected under peak strength conditions (Boulon et al. 2002). The present paper, similarly to the last-mentioned one, focuses on the laboratory determination of shear strength of jointed granitic rock masses. The samples were collected from Bátaapáti, where a new nuclear waste storage facility for low and medium-level radioactive waste is under construction. The tests were aimed at determining the peak and residual shear strength and angles of friction of granitoid rocks. The results are evaluated and interpreted by considering the various shear surface morphologies and lithologies for residual and peak stress conditions.

\section{Material}

The samples were collected from the tunnels of Bátaapáti, where the Hungarian nuclear waste storage facility is under construction. The site is located in South Hungary, within the Mórágy Hills, a small granitoid range (Balla et al. 2008, 2009) (Fig. 1). The storage site has two long access tunnels that lead to the chambers (Fábián et al. 2007). Large blocks of reddish-pinkish granitoids and smaller blocks of fault-filling greenish-grey clay were picked from the so-called "Big Loop" of the construction site using excavators. The location of the sampling site on the ground plan of the facility is shown in Fig. 2. The block samples are reddish-pink granitoid. Among the granitoids darker pinkish-red monzogranite (Fig. 3) with autoclastic breccia, and slightly carbonaceous rhodocrosite-bearing granitic samples were also found. 


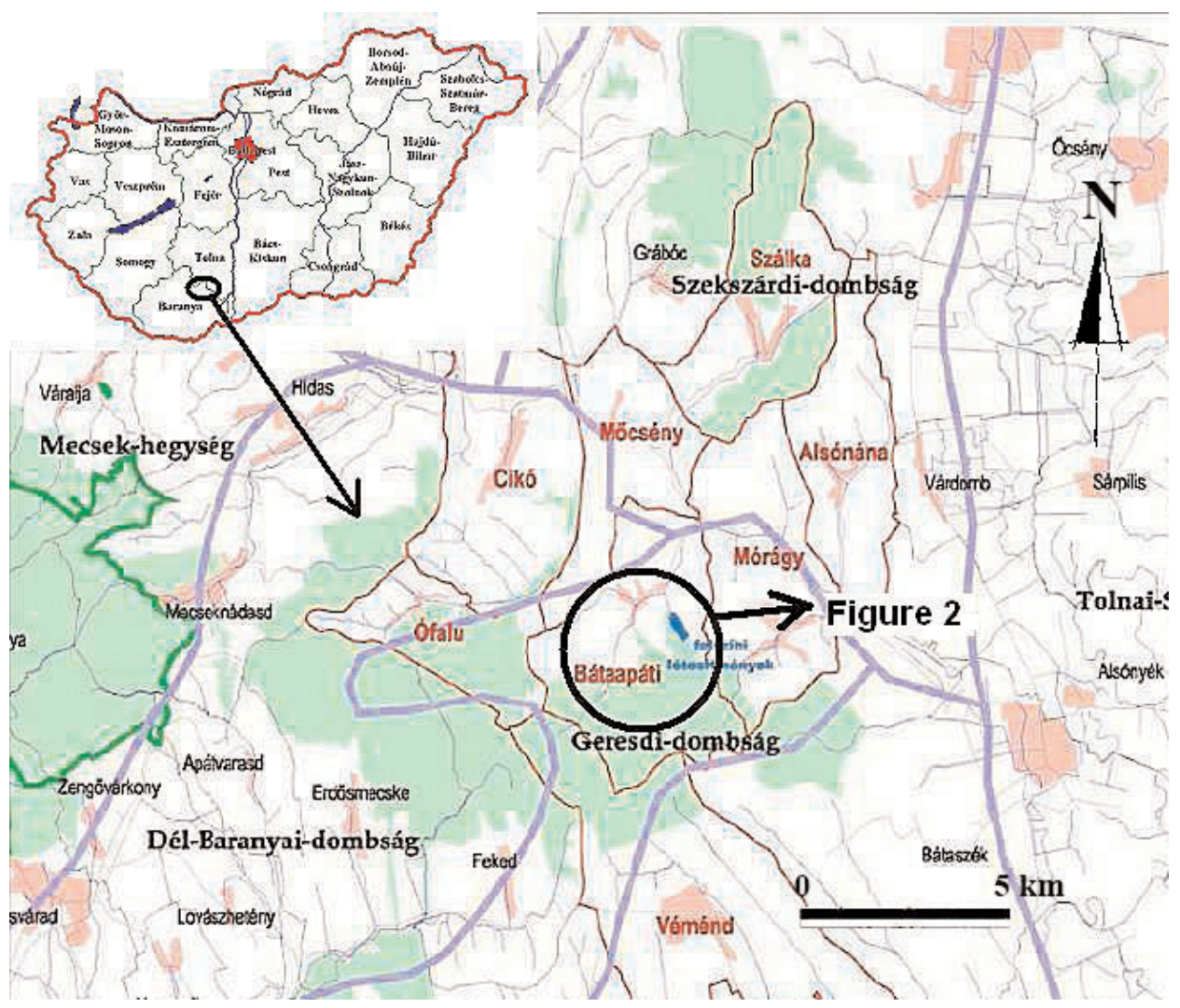

Fig. 1

Location of the Bátaapáti radioactive waste storage facility in South Hungary

\section{Methodology}

The direct shear strength tests were carried out according to the suggestions of the ISRM (1974). The test apparatus included a Controls 45-D548/1 shear box, with two manually operated hydraulic pumps that were used to exert normal and shear force. The maximum capacity of the hydraulic pumps was $50 \mathrm{kN}$. The shear load and normal load was recorded by test apparatus of 9861 (Kaliber Ltd). The normal and shear displacements were detected by HBM 1-WA/10MM-T displacement gauges, with a precision of $0.5 \%$ (Fig. 4). The measuring range of maximum displacement was $10 \mathrm{~mm}$.

From the larger blocks smaller specimens for shear strength tests were prepared by using diamond coring technique or by diamond cutter. Two types of samples were tested in terms of joint systems: i) samples with intentionally separated joints and ii) cut surfaces. The test specimens were placed in a sample 


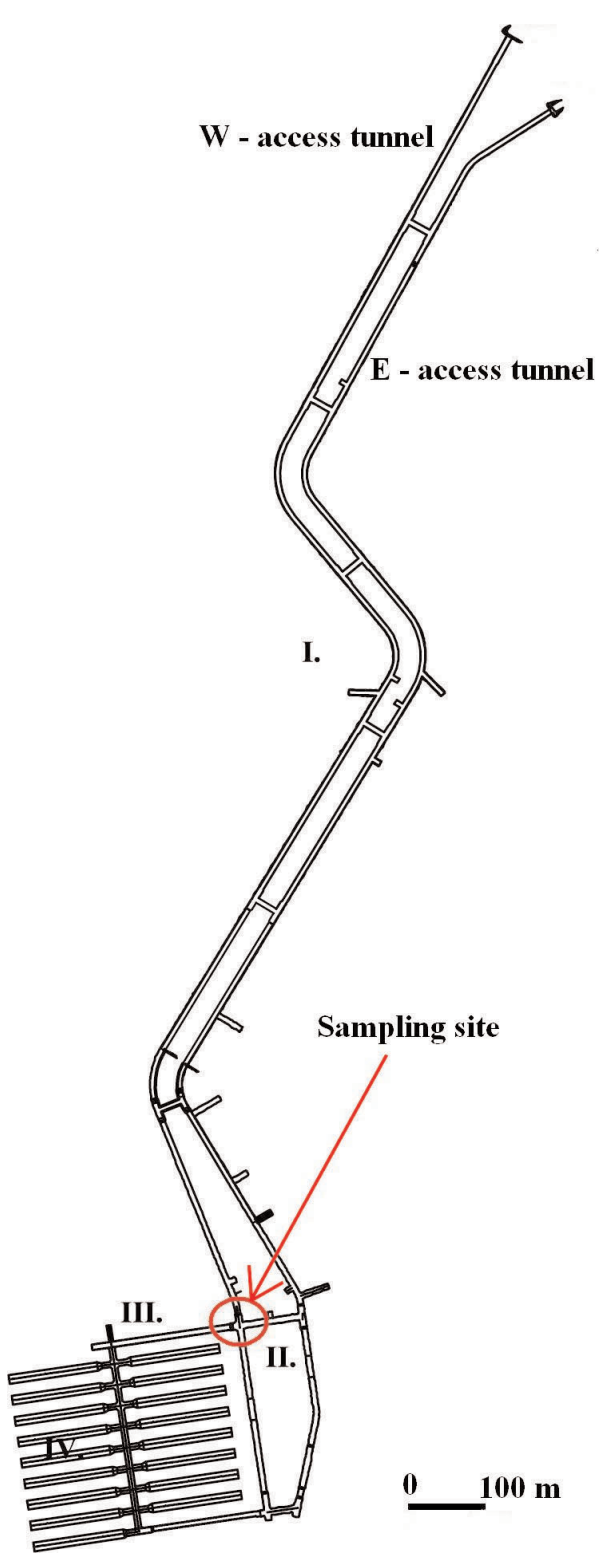

Fig. 2

Ground plan of the nuclear waste storage facility, showing the sampling site close to the future storage chambers preparation unit within an encapsulating material, which was plaster, according to the suggestions of the ISRM (1974). The samples were encapsulated in such a way that they would perfectly fit in the shear cell, in order to block the horizontal movement of the samples. The two halves were adjusted in such a way as to allow the closest alignment to the horizontal, i.e. to the shear surface (Fig. 5).

The surface area of the samples was measured. The surface roughness was recorded along two lines that were parallel to the applied main shear load. The latter was measured with displacement gauges, which were adopted to detect surface irregularities of $0.1 \mathrm{~mm}$ or larger in size.

Fig. 3

Close view of reddish-pink granitoid used for shear tests

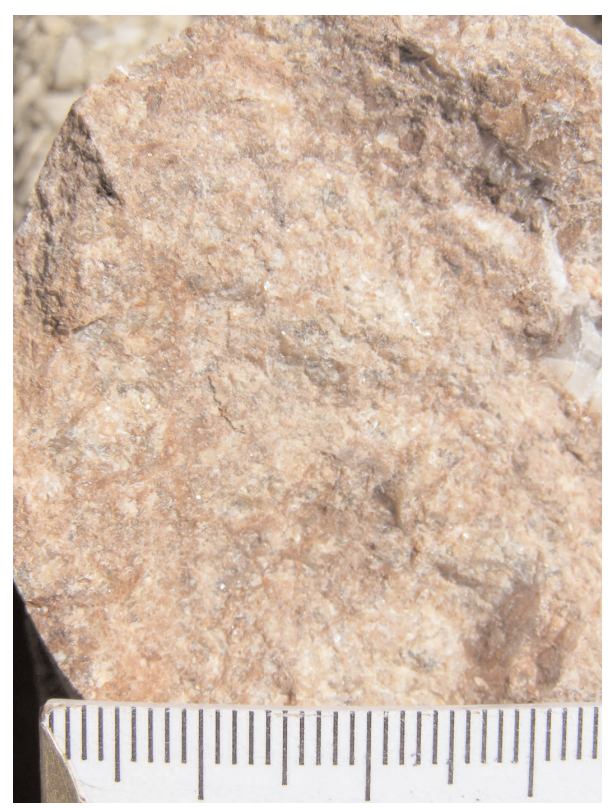




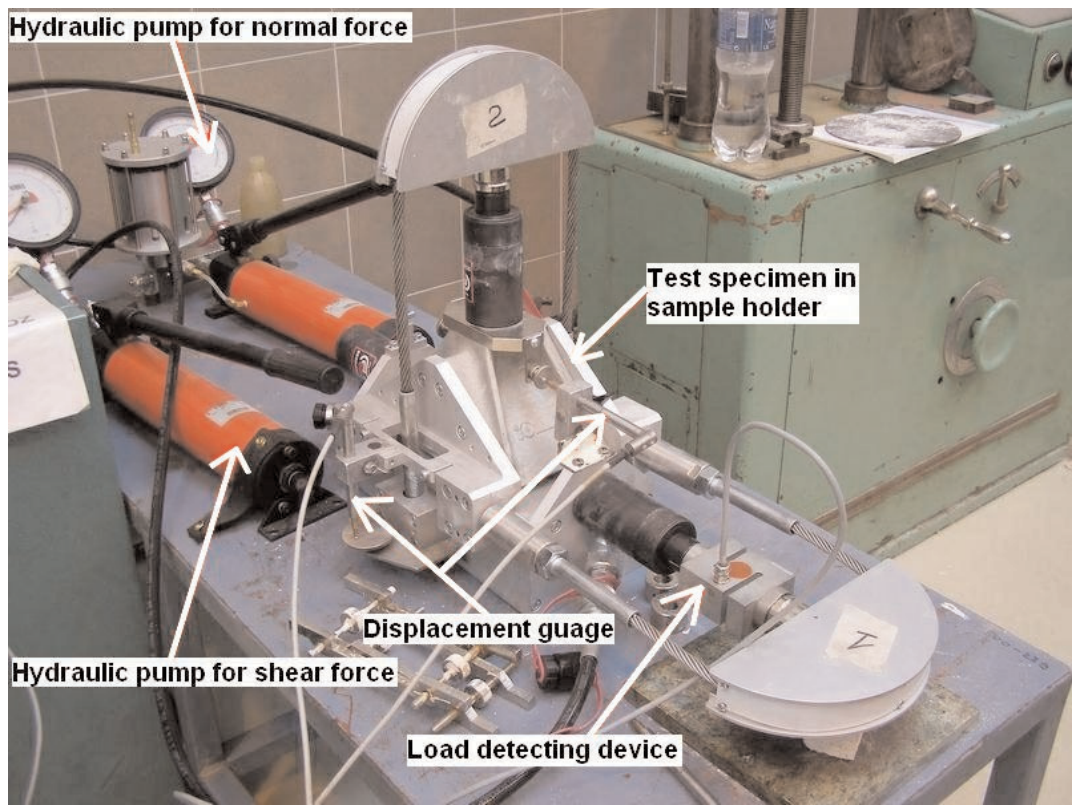

Fig. 4

The shear box with hydraulic pumps and displacement gauges used for the tests

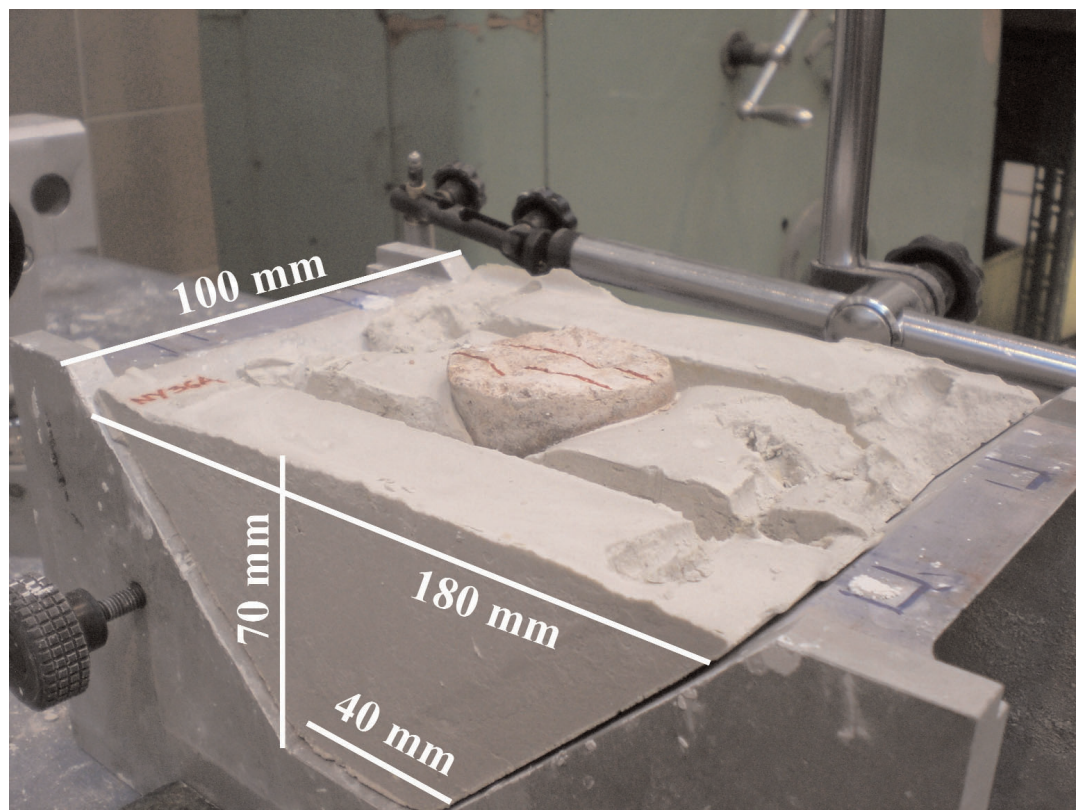

Fig. 5

Encapsulated sample in the sample preparation unit showing the main dimensions 
First normal load was applied and after the consolidation shear load was added. During the tests, different normal load was used in stages. The number of applied stages depended on the load-bearing capacity of the sample. The normal load was kept constant during each stage of the measurement. After the residual stage was reached the normal load was raised gradually and kept constant until the new residual stage was reached. Surface roughness influences the magnitude of the normal load. When samples with rough surfaces were tested, low normal load was applied $(0-15 \mathrm{kN})$ leading to a maximum of $8 \mathrm{MPa}$ normal stress.

\section{Results}

Beside lithological differences, the surface properties of specimens were very different from each other. Within the tested granitic rocks four separate groups were identified according to surface properties: i) rough surface (Fig. 6), ii) moderately rough surface, iii) cut surface and iv) calcite-covered joint surface (Fig. 7). The test results are given in Table 1.

Shear stress values were plotted against normal stress for rough surface and are shown in Fig. 8. The trend lines of maximum and residual stress values are very similar, which indicates that the samples behave similarly under shear stress. In the case of specimens with rough surfaces, the calculated

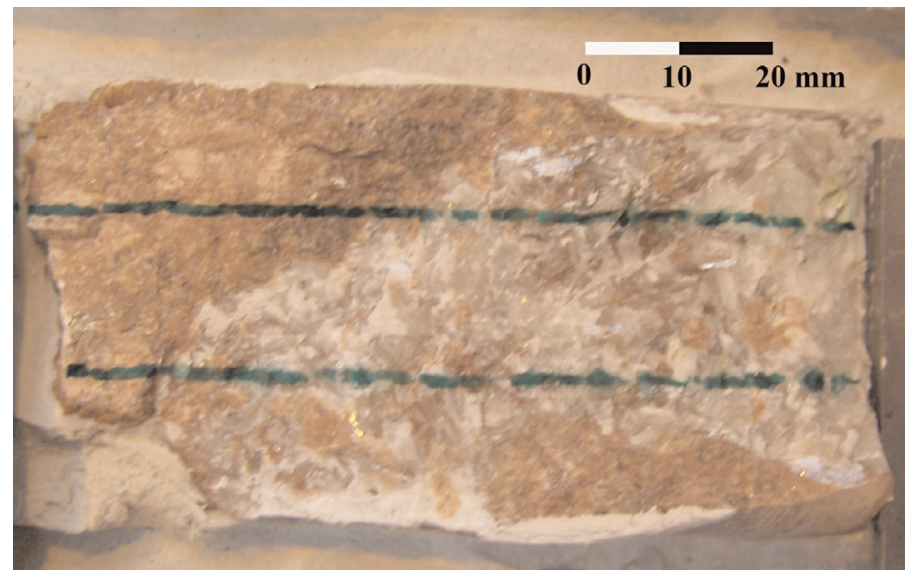

Fig. 7

Granite sample with calcite covered discontinuity surface (S 18) 


\begin{tabular}{|c|c|c|c|c|c|c|c|c|c|c|c|c|c|c|c|c|c|}
\hline 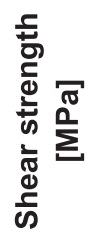 & $\begin{array}{l}\hat{A} \\
0\end{array}$ & $\stackrel{\infty}{\stackrel{\infty}{\sim}}$ & $\stackrel{\substack{\sim \\
\hdashline}}{0}$ & 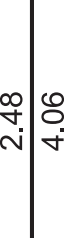 & $\stackrel{\mathcal{N}}{\leftarrow}$ & 苗 & $\stackrel{\stackrel{N}{\sim}}{\rightarrow}$ & & 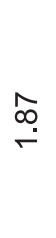 & $\stackrel{\stackrel{d}{\sim}}{\sim}$ & 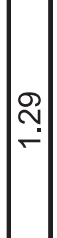 & $\stackrel{\infty}{\stackrel{\infty}{\leftarrow}}$ & $\mid \begin{array}{c}\infty \\
m \\
m\end{array}$ & ָָ & $\stackrel{\widehat{S}}{\text { N }}$ & $\stackrel{0}{\infty}$ & \\
\hline 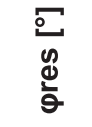 & $\begin{array}{l}\text { 옴 } \\
\stackrel{2}{-}\end{array}$ & $\begin{array}{l}\text { Nิ } \\
\text { N̦ }\end{array}$ & 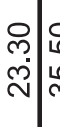 & 结 & $\begin{array}{l}\infty \\
\infty \\
\end{array}$ & $\begin{array}{l}\text { \& } \\
\text { న }\end{array}$ & $\begin{array}{l}\circ \\
\infty \\
+ \\
\end{array}$ & 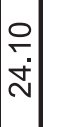 & $\begin{array}{l}\text { ల్ } \\
\text { ని }\end{array}$ & $\begin{array}{l}8 \\
\infty \\
\infty \\
\infty\end{array}$ & $\mid$\begin{tabular}{l}
0 \\
6 \\
9 \\
\hdashline \\
\end{tabular} & $\begin{array}{l}\infty \\
\infty \\
\infty\end{array}$ & $\mid$\begin{tabular}{l}
0 \\
\hdashline \\
\hdashline \\
\hdashline
\end{tabular} & 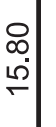 & $\begin{array}{l}8 \\
\stackrel{0}{\circ}\end{array}$ & 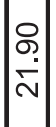 & 号 \\
\hline$\sum_{0}^{\pi}$ & ָָ & $\stackrel{N}{\stackrel{0}{0}}$ & $\begin{array}{l}\text { ৪) } \\
\text { ○. }\end{array}$ & : & ? & $\stackrel{8}{\circ}$ & 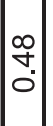 & & $\begin{array}{l}\widetilde{D} \\
0 \\
0 \\
0\end{array}$ & $\underset{0}{\sigma}$ & $\mid \begin{array}{c}\mathfrak{n} \\
\tilde{\omega} \\
0 \\
0\end{array}$ & $\begin{array}{l}n \\
0 \\
0\end{array}$ & 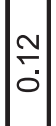 & $\stackrel{m}{\square}$ & $\begin{array}{l}\text { مீ } \\
0 \\
0\end{array}$ & $\mid \begin{array}{l}0 \\
0 \\
0\end{array}$ & \\
\hline $\begin{array}{l}\text { 뭉 } \\
\stackrel{\circ}{9}\end{array}$ & $\begin{array}{l}\text { 옹 } \\
\text { ¿ิ }\end{array}$ & $\begin{array}{l}\text { 尺े. } \\
\text { } \\
\text { సै }\end{array}$ & 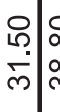 & & 오 & $\frac{8}{\dot{m}}$ & 울 & & $\begin{array}{l}\text { ᄋ } \\
\text { ळे }\end{array}$ & 을 & $\mid \begin{array}{l}8 \\
0 \\
0\end{array}$ & $\begin{array}{l}8 \\
\stackrel{0}{\circ}\end{array}$ & 움 & & $\begin{array}{l}\stackrel{8}{\circ} \\
\infty \\
\leftarrow\end{array}$ & $\begin{array}{l}\text { 울 } \\
\text { ì }\end{array}$ & \\
\hline $\begin{array}{l}\frac{r}{0} \\
\frac{0}{m}\end{array}$ & - & - & -1 & $-\mid-$ & $r$ & - & - & - & $\sim$ & $N$ & $|\sim|$ & $N$ & $\sim \mid$ & $\sim$ & $N$ & $|\sim|$ & $N$ \\
\hline 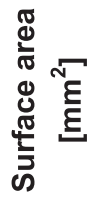 & 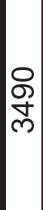 & 은 & 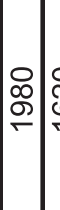 & ్ి유 & \begin{tabular}{l}
$\infty$ \\
\multirow{N}{*}{}
\end{tabular} & ஓ & $\frac{0}{\grave{N}}$ & $\begin{array}{l}\text { 엉 } \\
\stackrel{5}{\circ}\end{array}$ & $\frac{R}{i}$ & ి్ల్ర్ల్ల & $\frac{8}{\dot{\gamma}}$ & $\begin{array}{l}\text { O্ర } \\
\text { N }\end{array}$ & 冬 & 尽 & $\stackrel{\text { N }}{\stackrel{N}{N}}$ & & 令 \\
\hline $\begin{array}{l}\frac{0}{3} \\
\frac{0}{\sigma} \\
\frac{0}{0} \\
\frac{0}{E} \\
\text { 心 }\end{array}$ & $\frac{\frac{D}{0}}{\frac{0}{0}}$ & $\mid \frac{\Phi}{\frac{D}{0}}$ & 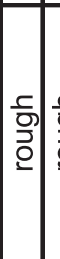 & 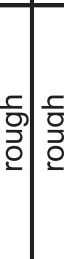 & $\begin{array}{l}\frac{}{0} \\
\frac{0}{2} \\
\frac{0}{0} \\
\frac{0}{0} \\
\frac{\pi}{0} \\
\frac{0}{0} \\
\text { ह }\end{array}$ & 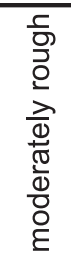 & $\mid \begin{array}{l}\text { 동 } \\
\text { 의 }\end{array}$ & 苛 & 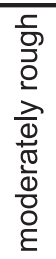 & 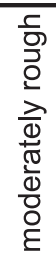 & $\frac{\mathbb{9}}{\frac{\mathrm{O}}{\mathrm{O}}}$ & 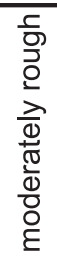 & $\mid \begin{array}{l}\frac{\mathbb{2}}{\mathrm{O}} \\
\frac{\mathrm{O}}{\mathrm{J}} \\
\mathrm{J}\end{array}$ & 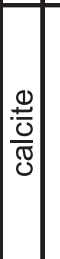 & 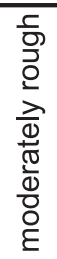 & & 苟 \\
\hline 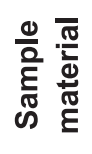 & 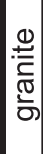 & 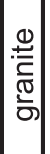 & 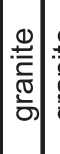 & 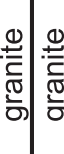 & 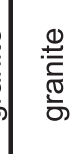 & 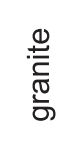 & 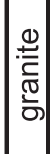 & 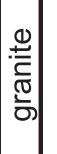 & 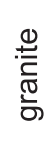 & 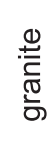 & 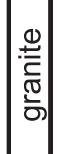 & 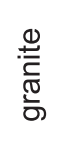 & 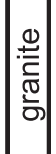 & 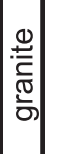 & 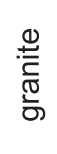 & 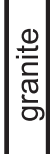 & 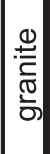 \\
\hline 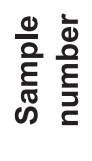 & $\frac{0}{\infty}$ & $\frac{N}{\omega}$ & mic & ఉ) & 음 & $\overline{\check{\infty}}$ & $\stackrel{\circ}{\infty}$ & $\bar{s}$ & $\stackrel{N}{\infty}$ & $\frac{m}{\infty}$ & $\frac{\infty}{\infty}$ & $\dot{\nabla}$ & $\frac{\Omega}{\infty}$ & స్లి & $\frac{\omega}{\infty}$ & & ஸै \\
\hline
\end{tabular}




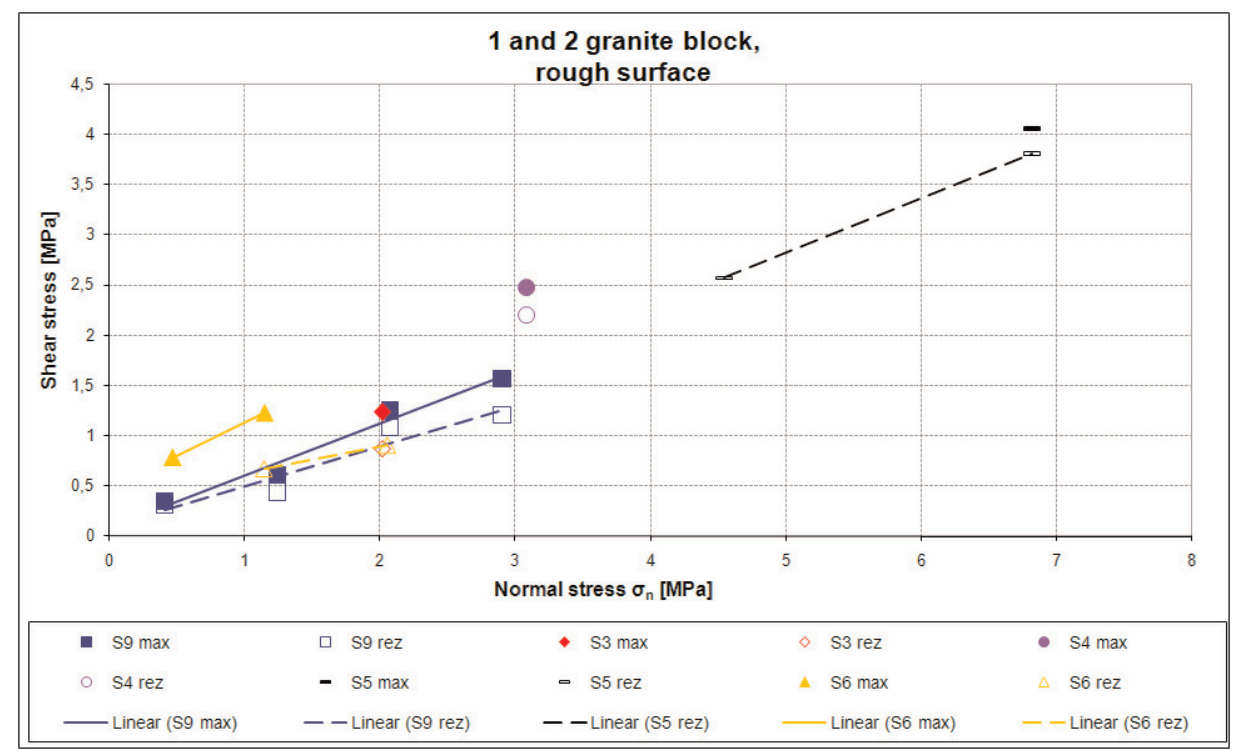

Fig. 8

Shear stress values plotted against normal stress for granite samples with rough surface (filled marks: maximum stress values, unfilled marks: residual stress values, continuous line: trend line for the maximum stress values, dashed line: trend line for the residual stress values)

angle of internal friction for maximum shear stress ranges between $27.4^{\circ}$ and $38.8^{\circ}$, with an average value of $32.4^{\circ}$, while for residual stress the value ranges between $14.8^{\circ}$ and $35.5^{\circ}$, with an average angle of $25.3^{\circ}$, respectively. The average apparent cohesion is $0.11 \mathrm{MPa}$ with calculated ranges of 0.0 to $0.48 \mathrm{MPa}$ (Table 2). Surface roughness data is between $5.3 \mathrm{~mm}$ and $10.2 \mathrm{~mm}$, with an average value of $7.8 \mathrm{~mm}$. The morphology of rough surface is very often similar to a sawtooth.

Specimens with moderately rough surfaces have relatively uniform roughness values. The measured amplitudes of the surfaces are between $7.3 \mathrm{~mm}$ to $8.9 \mathrm{~mm}$, with an average value of $8.3 \mathrm{~mm}$. When shear stress values are plotted against normal stress (Fig. 9) it is clear that the trend lines of maximum and residual stress values overlap more than those with rough surfaces (cf. Fig. 8). The average angle of internal friction for maximum shear stress is $24.2^{\circ}$ (ranges: $16.6^{\circ}-31.6^{\circ}$ ), and $21.7^{\circ}$ for residual stress, respectively. These values are lower than the ones of the tested rough surfaces. The average apparent cohesion is $0.63 \mathrm{MPa}$ (Table 2).

Calcite-covered joint surfaces with roughness values of 6.6 to $11.0 \mathrm{~mm}$ (average: $8.7 \mathrm{~mm}$ ) were tested. The surfaces were covered by sawtooth-like calcite crystals with visible cleavage planes of 3-4 $\mathrm{mm}^{2}$. The angle of internal friction for maximum shear stress was lower than that of the rough or moderately rough surfaces. Values of $16^{\circ}$ to $23.3^{\circ}$, with an average value of $19.4^{\circ}$ were calculated. Angle of friction for residual stress were very similar, with an average angle of $19.3^{\circ}$ (Fig. 10). The average apparent cohesion $0.42 \mathrm{MPa}$ (min. 0.12 MPa, 


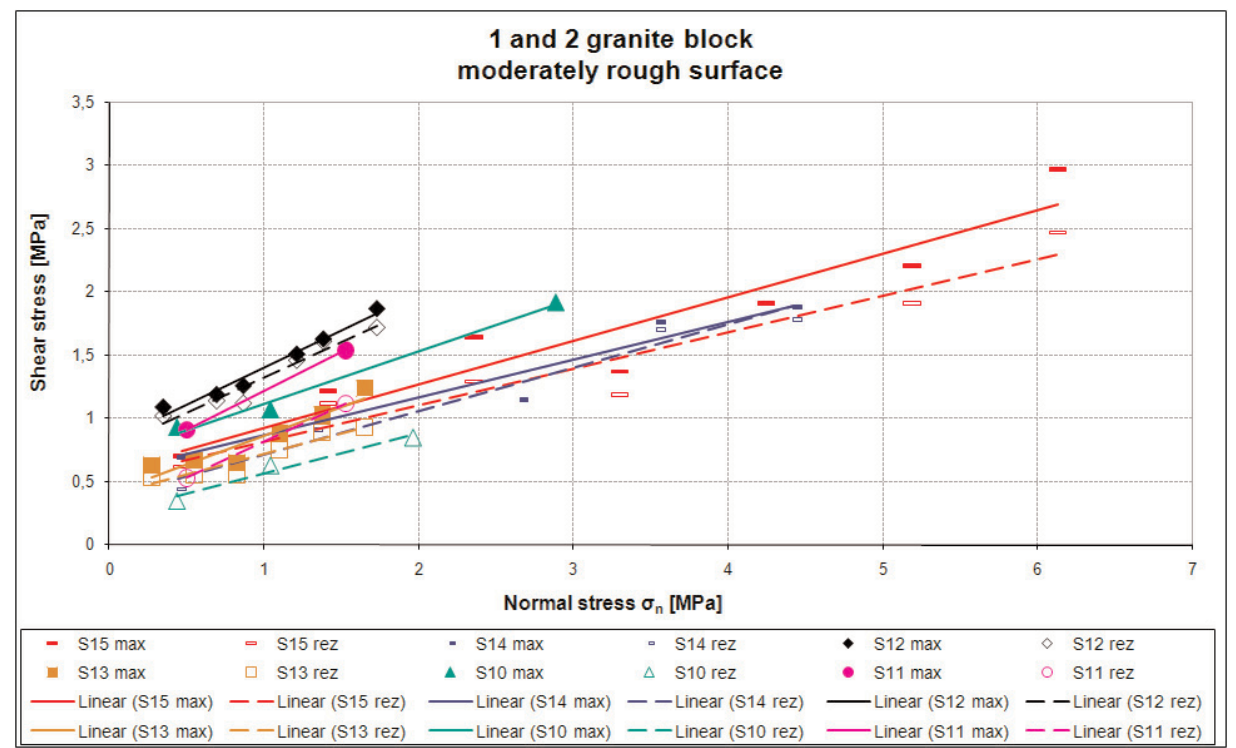

Fig. 9

Shear stress values plotted against normal stress for granite samples with moderately rough surface (filled marks: maximum stress values, unfilled marks: residual stress values, continuous line: trend line for the maximum stress values, dashed line: trend line for the residual stress values)

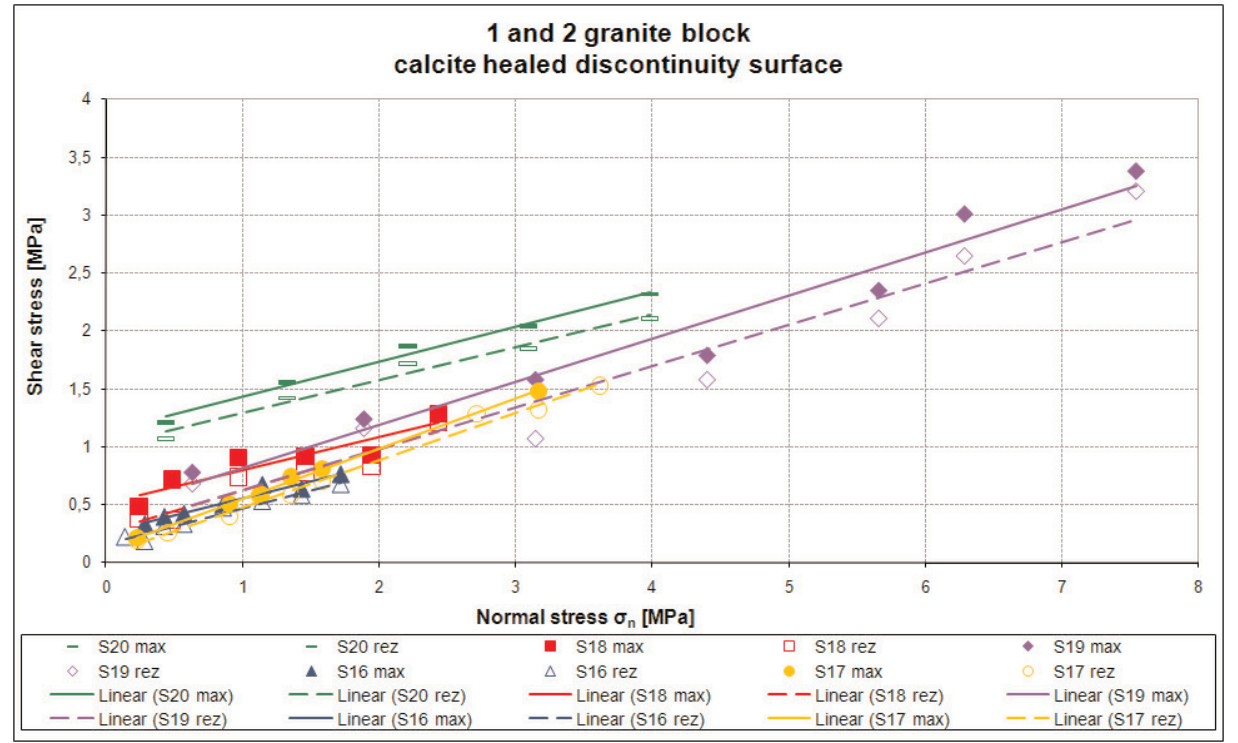

Fig. 10

Shear stress values plotted against normal stress for granite samples with calcite-covered joints (filled marks: maximum stress values, unfilled marks: residual stress values, continuous line: trend line for the maximum stress values, dashed line: trend line for the residual stress values) 
Table 2

Summary of the test results by sample groups with different surfaces (ave. - average)

\begin{tabular}{|c|c|c|c|c|c|c|c|c|c|}
\hline \multirow{2}{*}{$\begin{array}{l}\text { Sample group } \\
\text { (surface) }\end{array}$} & \multicolumn{3}{|c|}{$\varphi p\left[\left[^{\circ}\right]\right.$} & \multicolumn{3}{|c|}{ c [MPa] } & \multicolumn{3}{|c|}{ pres [ $\left.{ }^{\circ}\right]$} \\
\hline & $\min$ & $\max$ & ave. & $\min$ & $\max$ & ave. & $\min$ & $\max$ & ave. \\
\hline Rough & 27.40 & 38.80 & 32.40 & 0.00 & 0.48 & 0.11 & 14.80 & 35.50 & 25.30 \\
\hline Moderately rough & 16.60 & 31.60 & 24.20 & 0.41 & 0.82 & 0.63 & 16.00 & 29.90 & 21.70 \\
\hline Calcite & 16.00 & 23.30 & 19.40 & 0.12 & 1.13 & 0.42 & 15.80 & 22.20 & 19.30 \\
\hline Cut & & & & & & & 21.50 & 24.10 & 22.80 \\
\hline
\end{tabular}

max. $1.13 \mathrm{MPa}$ ) is between the cohesion values of rough and moderately rough surfaces (Table 2).

To understand the material properties of granite, diamond saw-cut surfaces from each granitic block were also tested in the shear box. The cut surfaces show very similar normal stress vs. shear stress graphs (Fig. 11). The calculated angle of internal friction for residual stress is $24.1^{\circ}$ and $21.5^{\circ}$ for the two tested samples, respectively (Table 1 ).

The average values of angle of friction and cohesion of tested surfaces are summarized in Table 2.

\section{Interpretation and discussion}

By comparing the graphic interpretation of the results (Figs 8-11) it can be seen that the steepness of the trend lines belonging to each tested group is similar. This suggests that the samples that were placed in one group had very similar properties and shear strength; in other words it justifies sample grouping according to surface properties. The different slopes of trend lines, which are actually the angle of friction, clearly represent the different behavior of tested shear surfaces. The highest angle of friction was measured on rough surfaces. In decreasing order of magnitude it was followed by the moderately rough surface, the cut surface and eventually the calcite-covered surface. It can be clearly seen that the samples with a rough surface have on average the greatest angle of friction for both peak and residual values. The measured angle of internal friction values for these rough granitic surfaces of the Bátaapáti site $\left(32.4^{\circ}\right)$ is within the range of what was found when South African granite was tested (Geertsema 2003). According to these test results the low values of $27.1^{\circ}$ of South African granites are related to very thin chloritic seams, while the peak values of $42.3^{\circ}$ were found when almost intact granites were tested under laboratory conditions. Nevertheless, when Geertsema (2003) calculated internal angle of friction by using Barton's formula, higher values were obtained, especially for chloritic granites $\left(56.4^{\circ}\right)$. This suggests that laboratory tests of direct shear strength are of 


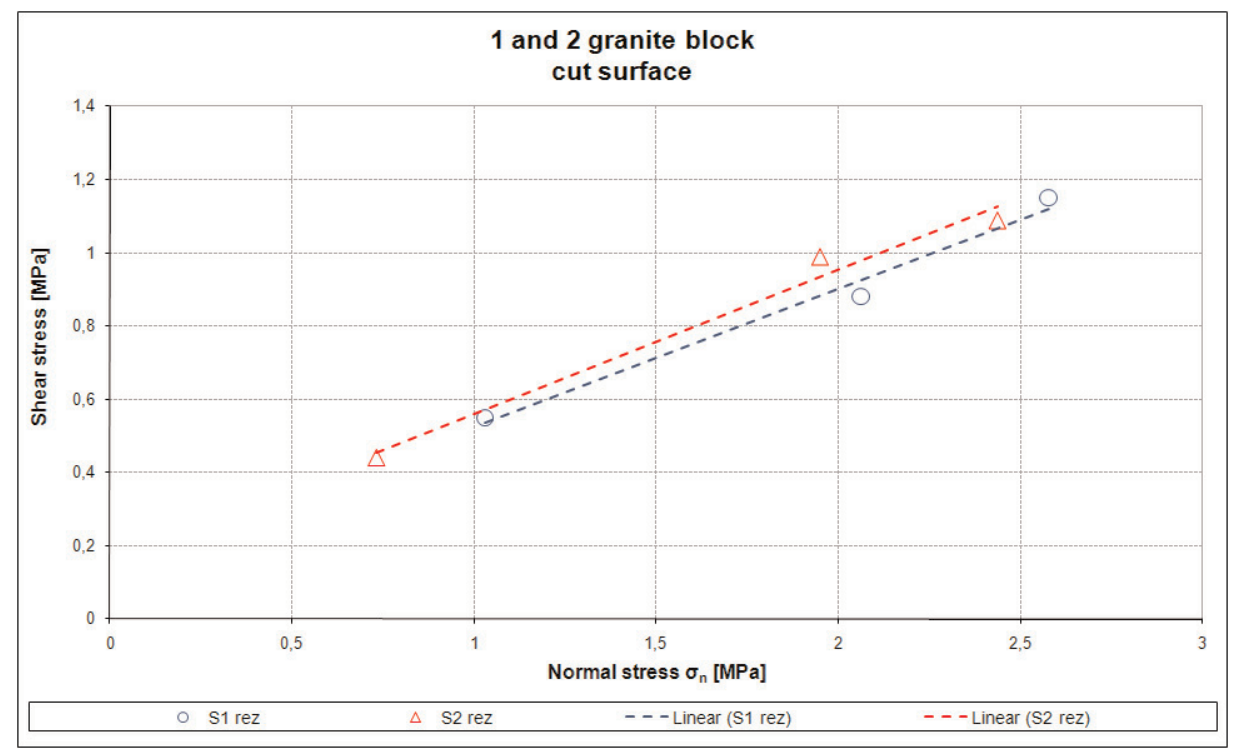

Fig. 11

Shear stress values plotted against normal stress for cut granite surfaces (unfilled marks: residual stress values, dashed line: trend line for the residual stress values)

crucial importance and provide more reliable data for tunnel design than the simple calculations.

While testing sandstone Towhata et al. (2001) found that the angle of internal friction for maximum and residual shear stress was $26.3^{\circ}$ and $27.6^{\circ}$, respectively. These lower values indicate the differences between the two lithologies, namely between sandstone and granite.

The angle of friction of calcite-covered joints was $19.4^{\circ}$ in the Bátaapáti shear tests, while in France during the direct shear tests of calcite-covered surfaces, values of $30^{\circ}$ were found (Boulon 2002). This is roughly $10^{\circ}$ more than what was obtained from the measurements in Hungary. This significant difference could be explained by the different quality of the two tested rocks and also by differences in testing methodology. It is also necessary to point out that the granitic rocks of Bátaapáti are more fractured than most other granites. This could be another explanation for the difference.

Some previous articles (Vásárhelyi 1999; Grasselli 2001) which dealt with direct shear tests attempted to outline rules to explain the shear properties of artificial rock surfaces. The results of these investigations provide similar examples, where the relationship between shear stress and normal stress values was established.

The limitations of direct shear tests are related to the encapsulation of samples, to the identification of surface roughness and to the area of sheared surfaces. These parameters significantly influence shear strength (ISRM 1974; Brady and 
Brown 2004); the improper identification of these data could lead to the misinterpretation of strength results.

\section{Conclusions}

The average angle of internal friction for tested granitic samples was between $19.4^{\circ}$ and $32.4^{\circ}$, indicating that surface properties significantly influence shear strength.

Surface roughness and surface properties have the highest influence upon shear strength when same lithologies are tested..

Within the samples obtained from granitic rocks the very rough surfaced specimens had the highest friction of angle, whereas the calcite-covered surfaces had the lowest.

The limitation of the interpretation and use of shear strength data is related to the fact that the determination of the sheared surface area is often difficult.

Direct laboratory shear tests that were carried out in the laboratory of the Department of Construction Materials and Engineering Geology have been shown to provide valuable data on the behavior of joints and were used as input parameters in the design of the Bátaapáti nuclear waste storage facility.

\section{Acknowledgements}

This work is connected to the scientific program of the " Development of quality-oriented and harmonized $\mathrm{R}+\mathrm{D}+\mathrm{I}$ strategy and functional model at BME" project. This project is supported by the New Széchenyi Plan (Project ID: TÁMOP-4.2.1/B-09/1/KMR-2010-0002). The technical help of the staff members of the laboratory of Department of Construction Materials and Engineering Geology, especially of Gy. Emszt, E.L. Árpás and B. Pálinkás, is appreciated.

\section{References}

Balla, Z., G. Császár, M. Földvári, Z. Gulácsi, L. Gyalog, I. Horváth, M. Kaiser, E. Király, L. Koloszár, B. Koroknai, Á. Magyari, Gy. Maros, I. Marsi, B. Musitz, E. Rálisch, Á. Rotárné Szalkai, T. Szocs, Gy. Tóth, J. Berta, Á. Csapó, G. Csurgó, Z. Gorjánácz, G. Hámos, Z. Hogyor, A. Jakab, I. Molnis, J. Ország, G. Szimoncsics, I. Szamos, G. Szebényi, I. Szucs, Z. Turger, A. Várhegyi, K. Benedek, P. Molbár, I. Szego, Gy. Tungli, A. Madarasi, Sz.E. Mártonné, Zs. Prónay, P. Tildy, G. Szongoth, M. Gacsályi, K. Moskó, L. Kovács, P. Mónus, B. Vásárhelyi 2008: A felszín alatti földtani kutatás zárójelentés, 1. kötet. (Summary Report of the Subsurface Geological Reserach, Volume 1) Kézirat, Magyar Állami Földtani Intézet, Budapest, RHK Kht., Paks, RHK-K-082/08, pp. 1-58, 132-154, 251-262, 635-655. (In Hungarian.)

Balla, Z., G. Császár, Z. Gulácsi, L. Gyalog, M. Kaiser, E. Király, L. Koloszár, B. Koroknai, Á. Magyari, Gy. Maros, I. Marsi, P. Molnár, Á. Rotárné Szalkai, Gy. Tóth 2009: A Mórágyi-rög északkeleti részének földtana. - Magyarázó a Mórágyi-rög ÉK-i részének földtani térképsorozatához (1:10 000) (Explanatory Notes to the Geological Map - series of North-eastern Part of the Mórágy Block). Magyar Állami Földtani Intézet, pp. 15-17. (In Hungarian.) 
Barton, N., V. Choubey 1977: The shear strength of rock joints in theory and practice. - Rock Mech., 10, pp. 1-54.

Boulon, M., G. Armand, N. Hoteit, P. Divoux 2002: Experimental investigations and modelling of shearing of calcite healed discontinuities of granodiorite under typical stresses. - Engineering Geology, 64, pp. 117-133.

Brady, B.H.G., E.T. Brown 2004: Rock mechanics for underground mining. - Kluwer, 628 p.

Fábián M., P.K. Bakainé, Zs. Tari, J. Bognár, I. Brandmüller, Z, Buócz, V. Keszerice, L. Kovács, L. Livo, Cs. Mátrai, I. Molnár, P. Molnár, G. Szebényi, B. Vásárhelyi, O. Viczencz 2007: A Bátaapátiban létesülő Nemzeti Radioaktívhulladék-tároló felszín alatti létesítményeinek múszaki tervdokumentációja (Technical Documentation of the Subsurface Works of the Bátaapáti National Radioactive Waste Disposal Site). - 9. melléklet, RHK Kft., RHK-K-055A/07, 36-63, pp. 93-98. (In Hungarian.)

ISRM 1974. Franklin, J. A.; Kanji, M.A. G. Herget and B. Ladanyi, K. Drozd and A. Dvorak, P. Egger, H. Kutter and F. Rummel, N. Rengers, M. Nose, K. Thiel, F. Peres Rodrigues and J.L. Serafim, Z.T. Bieniawski and T.R. Stacey, F. Muzas, R.E. Gibson and N.B. Hobbs, J.H. Coulson, D.U. Deere, R.K. Dodds, H.B. Dutro, A.K. Kuhn and L.B. Underwood 1974: Suggested Methods for Determining Shear Strength. - International Society for Rock Mechanics Commission on Standardization of Laboratory and Field Tests, Document No. 1., pp. 131-140.

Gálos, M., B. Vásárhelyi 2006: Kőzettestek osztályozása az építőmérnöki gyakorlatban (Rock Mass Classification in Civil Engineering Practice). - A Budapesti Múszaki és Gazdaságtudományi Egyetem Építőmérnöki kar Építőanyagok és mérnökgeológia kiadványa, Budapest, Múegyetemi Kiadó, 144 p. (In Hungarian.)

Geertsema, A.J. 2003: The shear strength of rock joints with special reference to dam foundations. Presented as partial fulfillment for the PhD degree: Engineering Geology, in the Faculty of Natural and Agricultural Sciences, University of Pretoria; p. 132.

Grasselli, G. 2001: Shear Strength of Rock Joints based on Quantified Surface Description. - EPFLausanne, Switzerland.

Ladanyi, B., G. Archambault 1970: Simulation of the shear behaviour of a jointed rock mass. - In: Proc. 11th U.S. Symposium on Rock Mechanics. Berkeley, pp. 105-125.

Patton, F.D. 1966: Multiple modes of shear failure in rock. - In: Proc. 1st Congress of International Society of Rock Mechanics, Lisbon, Portugal, pp. 509-513.

Towhata, T., H. Yamazaki, M. Kanatani, C. Lin, T. Oyama 2001: Laboratory Shear Tests of rock Specimens Collected From Site of Tsao-Ling Earthquake-induced Landslide. - Tamkang Journal of Science and Engineering, 4/3, pp. 209-219.

Vásárhelyi, B. 1999: Shear failure in rock using different constant normal load. - Periodica Polytechnica Ser. Civ. Eng., 43/2, pp. 179-186. 